\title{
Lung Mature B-Cell Neoplasm
}

National Cancer Institute

\section{Source}

National Cancer Institute. Lung Mature B-Cell Neoplasm. NCI Thesaurus. Code C60310.

A neoplasm that arises from mature B-lymphocytes or plasma cells in the lung.

Representative examples include bronchial mucosa-associated lymphoid tissue

lymphoma, diffuse large B-cell lymphoma, lymphomatoid granulomatosis, and primary

pulmonary plasmacytoma. 